Menara Perkebunan, 2001 69(2), 58-70

\title{
Analisis abnormalitas tanaman kelapa sawit (Elaeis guineensis Jacq) hasil kultur jaringan dengan teknik Random Amplified Polymorphic DNA (RAPD)
}

Analysis abnormalities of oil palm (Elaeis guineensis Jacq) from tissue culture

by Random Amplified Polymorphic DNA (RAPD)

\author{
Nurita TORUAN-MATHIUS ${ }^{1)}$, Saro Ina Ita BANGUN ${ }^{2)} \&$ \\ MARIA-BINTANG ${ }^{3)}$ \\ ${ }^{1)}$ Unit Penelitian Bioteknologi Perkebunan, Bogor 16151, Indonesia \\ 2) Jurusan Biologi, Universitas Nasional, Jakarta \\ 3) Jurusan Biologi, Institut Pertanian Bogor, Bogor
}

\section{Summary}

Problem in oil palm propagation through tissue culture is the abnormality of reproductive organs i.e. female flowers and mantle fruits are in the same plants or clones. Various abnormalities obtained between clones, and could only be identified after fruit formation. The experiment was conducted to analyze genetic similarities of normal and abnormal genotypes in the same and among clones, and also to get a specific RAPD band as a marker for abnormalities. Six clones of oil palm (16 genotypes) of 5-year old MK152, MK203, MK209 and MK212 with normal fruits, female flowers, and abnormal fruits (heavy mantled), grown in the field, while two other clones were MK 104 and MK 176 with normal fruits and heavy mantled. PCR reaction to amplify DNA of 16 genotypes using 15 random primers. Genetic similarities and dendogram were done by NTSYS-pc, while honestly value of UPGMA analyzed by boostrap with WinBoot program. The results showed that $O P C-07$, OPC-09, OPW-19 and SC10-19 were able to determine the differences of normal and abnormal genotypes in the same clone of six clones tested. While other primers were only able to differentiate between normal and abnormal genotypes only in several clones. Genetic similarities among 16 genotypes tested were around 0.47-0.96. Genetic similarities between normal genotype were higher than that of among abnormal genotypes. MK176 clone was more stable in culture as compare to other clones. UPGMA showed that in generaly normal genotypes and abnormal one, in the same clones belongs to the same group. The results of principalcomponent analysis showed that from 15 primers tested no specific DNA band could be used as a marker for abnormalities. To obtaine have DNA markers, a more sensitive technique for DNA analysis is needed.

[Key words:Elaeis guineensis, fruit abnormalities, flower abnormalities, somaclonal variation, RAPD marker, genetic similarity, UPGMA analysis]

\section{Ringkasan}

Masalah yang dihadapi dalam perbanyakan tanaman kelapa sawit dengan teknik kultur jaringan adalah abnormalitas organ reproduktif yaitu terbentuknya bunga jantan dan buah mantel dalam klon yang sama. Terjadinya abnormalitas sangat beragam, dan teridentifikasi setelah tanaman berbuah. Penelitian ini bertujuan untuk mengetahui kesamaan genetik serta pengelompokan antar genotipe normal dan abnormal dalam klon yang sama maupun antar klon, serta menetapkan pita DNA penciri untuk abnormalitas dengan RAPD. Enam klon kelapa sawit(16 genotipe) berumur 5 tahun yaitu MK152, MK203, MK209, dan MK212 masing-masing dengan genotipe berbuah normal, berbunga jantan, dan berbuah abnormal (mantel berat). Dua 
Analisis abnormalitas tanaman kelapa sawit......

klon lainnya yaitu MK104 dan MK176 masingmasing terdiri dari genotipe berbuah normal dan mantel berat. Reaksi PCR untuk mengamplifikasi DNA contoh dilakukan menggunakan 15 primer acak. Kesamaan genetik dan pembuatan fenogram dilakukan dengan program NTSYS-pc. Sedang tingkat kepercayaan UPGMA ditetapkan dengan analisis bootstrap menggunakan program WinBoot. Hasil yang diperoleh menunjukkan bahwa primer OPC-09, SC10-19, OPC-07 dan OPW-19 mampu membedakan genotipe normal dan abnormal dalam klon yang sama untuk keenam kon yang diuji. Sedang primer lainnya hanya mampu menunjukkan perbedaan antar genotipe normal dan abnormal dalam beberapa klon saja. Kesamaan genetik antar 16 genotipe yang diuji berkisar antara 0,47-0,96. Kesamaan genetik antar genotipe normal lebih tinggi dibandingkan dengan kesamaan genetik antar genotipe abnormal. Klon MK176 lebih stabil dalam kultur dibandingkan dengan klon lainnya. UPGMA menunjukkan bahwa umumnya genotipe normal dan abnormal dalam klon yang sama berada dalam satu grup. Hasil analisis komponen utama menunjukkan bahwa dari 15 primer yang diuji belum mampu menghasilkan pita DNA penciri untuk abnormalitas. Untuk mendapatkan pita DNA penciri, perlu dilakukan analisis DNA dengan teknik yang lebih sensitif untuk mendeteksi perubahan satu basa oligonukleotida

\section{Pendahuluan}

Salah satu yang umum ditemukan pada klon kelapa sawit yang dihasilkan dari kultur jaringan adalah terjadinya perubahan 10$40 \%$ ke arah abnormalitas pada organ reproduktif yaitu bunga dan buah. Dalam proses abnormalitas ini terjadi konversi satu atau lebih primordial anter menjadi karpel tambahan yang lunak dan berkembang menjadi buah mantel (Corley et al., 1986).
Hal yang sangat ekstrim dari abnormalitas ini adalah tidak terbentuknya buah karena tandan buah dipenuhi oleh bunga jantan atau buah bermantel berat yang menyebabkan hilangnya produksi. Tidak adanya kualitas kontrol yang efektif untuk abnormalitas pada produksi, dan belum lengkapnya pemahaman mengenai penyebab abnormalitas di dalam perkembangan kultur in vitro berakibat pada tertundanya upaya untuk memproduksi bibit unggul kelapa sawit secara klonal.

Untuk mengatasi masalah tersebut dalam beberapa tahun terakhir ini beberapa kelompok peneliti dari Inggris, Malaysia, Kolombia dan Papua New Guinea telah melakukan kajian dan penelitian untuk menyempurnakan protokol teknik kultur jaringan yang digunakan untuk memproduksi bibit klonal yang unggul. Penyempurnaan dilakukan dengan tujuan menekan abnormalitas.

Ada beberapa pendapat mengenai terjadinya abnormalitas pada tanaman kelapa sawit hasil kultur jaringan, perubahan tersebut dapat bersifat genetik (Rao \& Danough, 1990), gangguan ekspresi gen diakibatkan fitohormon (Jones, 1991 \& Paranjothy et al., 1993), struktur kalus (Pannetier et al., 1981; Ahee et al., 1981 \& Duran-Gasselin et al., 1993) lamanya subkultur dan umur kalus (Paranjothy et al., 1993), tekanan seleksi yang dipakai, jenis eksplan yang digunakan, level ploidi sumber eksplan dan kecepatan proliferasi kalus (Skirvin et al., 1984; Karp, 1995). Larkin \& Scowcroft (1991) menyatakan bahwa variasi pada tanaman yang diregenerasi dari kultur jaringan disebut sebagai variasi somaklonal.

Variasi somaklonal kemungkinan disebabkan ketidakaturan mitotik yang berperan dalam terjadinya ketidakstabilan kromosom, terjadi amplifikasi atau delesi seperti inaktif gen atau aktif kembali gengen silent. Peschke \& Philips (1992) menyatakan bahwa beberapa tipe utama 
Toruan-Mathius et al.

variasi genetik somaklonal adalah aberasi kromosom, aktivitas elemen transposon, dan terjadinya metilasi DNA. Frekuensi variasi somaklonal tergantung pada cara regenerasi planlet. Planlet yang diregenerasi dari kalus yang tidak terorganisir lebih bervariasi dibandingkan dengan kalus yang terorganisir, sebaliknya hanya sedikit terjadi pada planlet yang diregenerasi langsung tanpa melalui fase kalus (Mohan \& De Klerk, 1998; Bouman \& De Klerk, 1996). Menurut Meyer et al. (1994) pada tanaman tinggi metilasi sitosin yang berat memegang peranan penting dalam ekspresi gen selama dalam perkembangan dan diferensiasi. Pola hiper dan hipometilasi DNA yang diinduksi dalam sistem kultur dapat ditransmisikan ke tanaman hasil regenerasi dari kultur tersebut. Dalam medium yang mengandung auksin dengan konsentrasi tinggi, metilasi mengalami peningkatan.

Beberapa penelitian dengan pendekatan molekuler telah dilakukan untuk memahami masalah abnormalitas pada klonklon kelapa sawit di antaranya dengan teknik Random Amplified Polymorphic DNA (RAPD). Nuhaimi-Haris \& Darussamin (1997) telah menemukan bahwa beberapa nomor primer acak dari ABI (Bresatec, Australia) dan OP (Operon, USA) yang digunakan dalam analisis RAPD mampu membedakan antar individu tanaman kelapa sawit yang berbuah normal dan abnormal dari klon yang sama, khususnya beberapa nomor dari klon SOC, MK, LMC dan BC. Namun, tidak ditemukan pita DNA spesifik yang dapat membedakan tanaman yang berbuah normal dengan yang abnormal secara universal. Nurhaimi-Haris (1998) mendeteksi perbedaan genetik beberapa nomor klon SOC, LMC, dan MK tanaman kelapa sawit yang berbuah normal dan abnormal serta melakukan analisis pengelompokan klon-klon tersebut berdasarkan analisis RAPD. Pada penelitian ini digunakan 12 macam primer acak dari
Bresatec, Australia yaitu Abi 117.13, Abi 117.16, Abi 117.17, Abi 117.18, Abi 117 19, Abi 117.20, Abi 117.21 dan primer OPB 04, OPB07, OPB20, OPH03, dan OPC05 dari Operon, USA. Hasil yang diperoleh menunjukkan bahwa ada kecenderungan individu tanaman yang berbuah normal dan tidak normal dari satu klon yang sama berada dalam satu kelompok. Diperoleh juga bahwa klon SOC mempunyai variasi genetik lebih tinggi dibandingkan dengan klon LMC dan MK. Hal ini menunjukkan bahwa klon SOC cenderung tidak stabil apabila diperbanyak secara in vitro.

Penelitian ini bertujuan mendapatkan informasi yang lebih jauh mengenai pemanfaatan RAPD untuk menganalisis keragaman genetik, pengelompokan genotipe yang diuji (normal dan tidak normal), menetapkan klon yang lebih stabil di dalam kultur, maupun menetapkan pita pembeda antar klon-klon kelapa sawit yang berbuah normal dan abnormal.

\section{Bahan dan Metode}

\section{Bahan tanam}

Bahan tanaman yang digunakan dalam penelitian ini adalah enam klon kelapa sawit berumur 5 tahun yang dipelihara di Kebun Percobaan milik Badan Pengkajian dan Penerapan Teknologi, Ciampea, Bogor. Bahan tanaman ini hasil perbanyakan dengan kultur jaringan, Balai Penelitian Marihat, Pematang Siantar. Empat klon yaitu MK152, MK209, MK212 dan MK203, masing-masing terdiri dari individu tanaman yang berbunga jantan, berbuah abnormal(buah mantel berat) dan normal. Dua klon yaitu MK176, MK104, masingmasing terdiri dari genotipe berbuah normal dan abnormal (Gambar 1 \& 2). Seluruh contoh yang dianalisis adalah sebanyak 16 genotipe. 
Analisis abnormalitas tanaman kelapa sawit.....
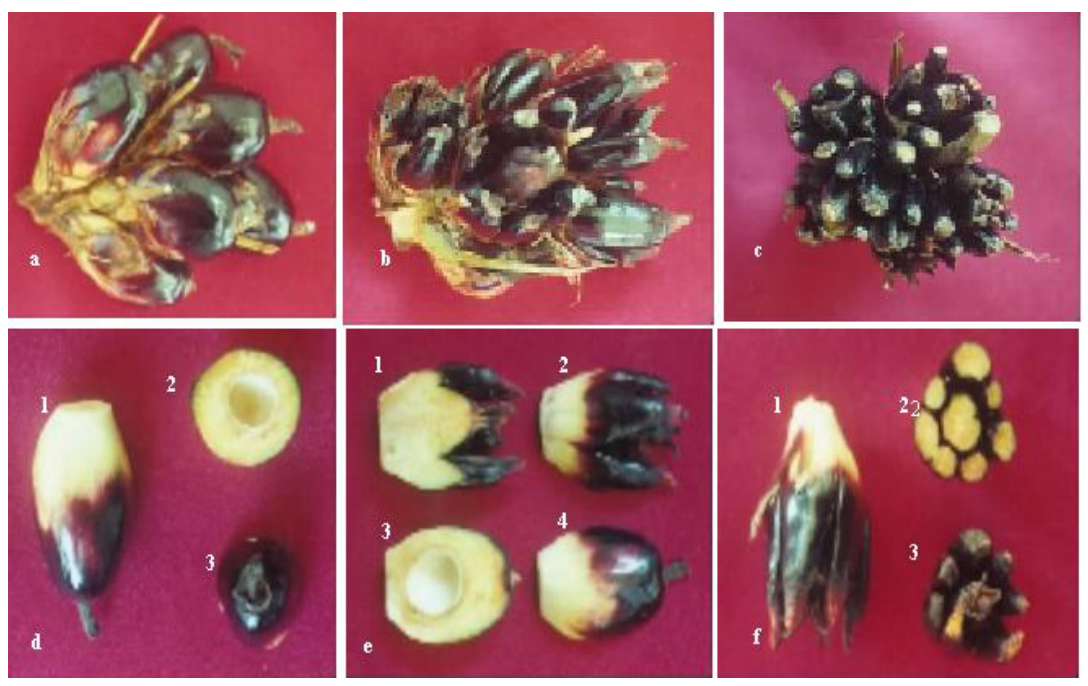

Gambar 1. Buah kelapa sawit dari tanaman klonal hasil kultur jaringan (a) buah normal; (b) buah mantel ringan; (c) buah mantel berat; (d) buah normal dan penampang melintang (d2 \&3); (e) penampang melintang dan membujur buah matel ringan (e1 \& 2) dan buah normal (e3 \&4); (f) buah mantel berat-bersayap (f1), penampang melintang (f2) dan tampak atas (f3).

Figure 1. Oil palm fruits of clonal plant from tissue culture (a) normal fruit; (b) light mantled fruit; (c) heavy mantled fruit; (d) normal fruit and cross section (d2 \& 3); (e) cross section and longitudinal light mantled fruit (e1 \&2) and normal fruit (e3\& 4); (f) heavy mantled fruit-wings (f1), cross section (f2) and upper part (f3)
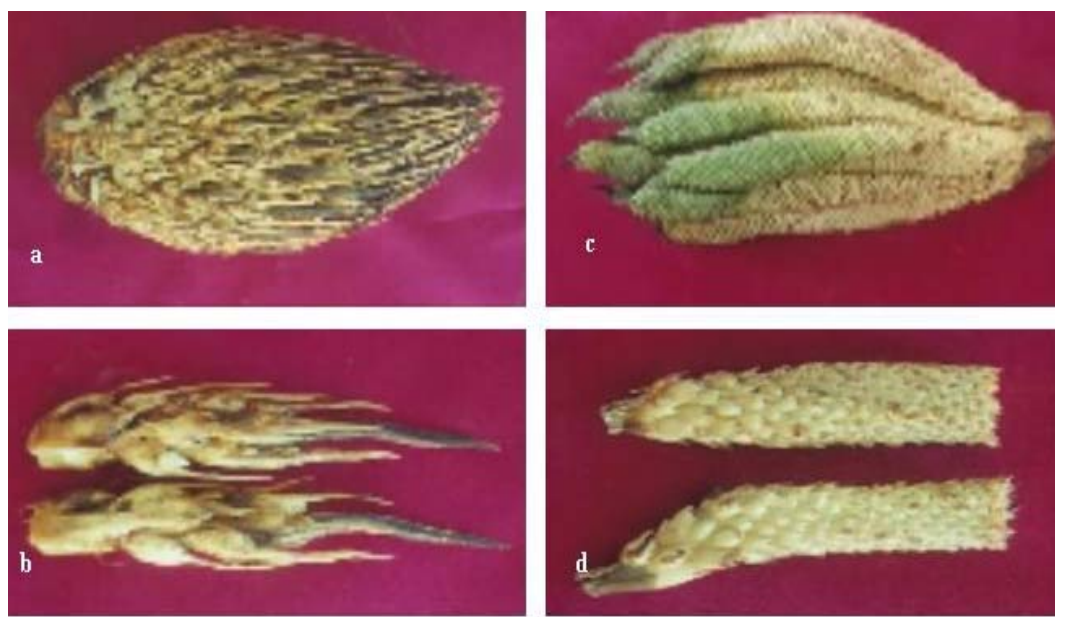

Gambar 2. (a) Buah kelapa sawit mantel berat bersayap; (b) bentuk buah bersayap; (c) bunga jantan; (d) bunga jantan steril

Figure 2. Oil palm fruit heavy mantled wings; (b) performance of wings fruit; (c) famale flower; (d) sterile famale flower 
Toruan-Mathius et al.

\section{Isolasi DNA genom dan reaksi PCR}

DNA diekstraksi dari daun muda sebanyak 0,3 g dari klon enam MK normal dan abnormal menurut metode Orozco Castillo et al. (1994) yang telah dimodifikasi Toruan-Mathius \& Hutabarat (1996). Pengujian kualitas dan kuantitas DNA dilakukan menurut Sambrook et al. (1989). Amplifikasi DNA dengan PCR berdasarkan metode William et al. (1990). Reaksi PCR sebanyak $25 \mu \mathrm{L}$ mengandung 50 ng DNA genomik dari masing-masing contoh yang diuji, 1 Unit Taq polimerase, dATP, dCTP, dGTP, dan dTTP masing-masing dengan konsentrasi $0,1 \mathrm{mM}$. Untuk mencegah penguapan pada saat reaksi berlangsung maka contoh dilapisi dengan $25 \mathrm{~mL}$ mineral oil.

Reaksi amplifikasi dilakukan menggunakan alat Thermal Cycler (Thermolyne, Amplitron-I) yang diprogram satu siklus denaturasi awal pada suhu $94^{\circ} \mathrm{C}$ selama 2 menit, diikuti dengan 45 siklus yang terdiri atas denaturasi pada suhu $94^{\circ} \mathrm{C}$ selama 1 menit, anealing pada suhu $36^{\circ} \mathrm{C}$ selama 1 menit dan ekstensi pada suhu $72^{\circ} \mathrm{C}$ selama 4 menit.

Produk amplifikasi difraksinasi dengan $1,4 \%$ gel agarosa menggunakan elektroforesis dalam $1 \mathrm{X}$ bufer TAE dan migrasi dijalankan pada 50 volt selama 1 jam 15 menit. Gel diberi pewarnaan dengan $5 \mathrm{lg} / \mathrm{mL}$ EtBr, kemudian dicuci dengan akuades. Hasil elektroforesis divisualisasikan dengan UV transiluminator dan didokumentasi dengan film Polaroid 665.

Untuk memperoleh primer yang mampu menghasilkan pita dalam jumlah banyak dan tegas, pada tahap awal dilakukan seleksi terhadap 40 primer acak 10-mer (Operon Alameda Tech). Selanjutnya primer yang terpilih digunakan dalam percobaan analisis RAPD pada klon kelapa sawit dengan genotipe normal dan abnormal.

\section{Analisis Data RAPD}

Untuk menentukan kesamaan genetik antar genotipe yang dianalisis, seluruh pita DNA yang polimorfik ditetapkan dengan ada (1) dan tidaknya (0) pita yang sama. Pita fragmen DNA yang dibaca dari hasil elektroforesis adalah yang tergolong tajam dan medium. Kesamaan antar genotipe ditentukan menurut Nei \& Li (1979). Pengelompokan data matriks dan pembuatan dendogram dilakukan dengan metode Unweighted Pair-Group Method With Arithmetic (UPGMA), fungsi Similarity Qualitative (SIMQUAL) menggunakan program komputer NTSYS-pc (Rohlf, 1993).Tingkat kepercayaan dari dendogram berdasar UPGMA ditentukan melalui analisis bootstrap menggunakan program WinBoot dengan pengulangan 2000 kali (Yap \& Nelson, 1996).

Diagram pencar dua dimensi dibuat berdasarkan analisis komponen utama (AKU) yaitu analisis yang mereduksi banyaknya peubah asal menjadi beberapa peubah baru yang dapat menjelaskan keragaman data asal, menggunakan program MINITAB 11.12.

\section{Hasil dan pembahasan}

Dari 40 primer yang diseleksi, terpilih 15 primer yang mampu memberikan pita DNA sekitar 3-14 untuk masing-masing primer. Amplifikasi DNA dengan 15 primer yang digunakan menghasilkan fagmen DNA dengan berat molekul berkisar antara 200$2500 \mathrm{pb}$. Hasil yang diperoleh menunjukkan bahwa primer OPC-07,OPC-09, SC10-19 dan OPW-19 mampu menunjukkan perbedaan genotipe yang berbuah normal dan tidak normal pada masing-masing klon yang diuji yaitu MK152, MK209, MK212, MK203, MK176, dan MK104. Sedang OPH18 hanya mampu membedakan genotipe berbuah normal dan tidak normal pada klon 
Analisis abnormalitas tanaman kelapa sawit......

MK176. Primer lainnya umumnya juga mampu menunjukkan perbedaan genotipe tanaman normal dan abnormal dalam satu klon yang sama, pada beberapa klon yang diuji. Perbedaan pola pita DNA klon MK212 dan MK104 dengan genotipe normal dan abnormal dapat terdeteksi dengan 11 primer (Tabel 1). Salah satu contoh hasil amplifikasi DNA genotipe yang diuji disajikan dalam Gambar 3.

Dari hasil yang diperoleh tampak bahwa perbedaan antar genotipe tanaman yang berbuah normal dan abnormal dalam satu klon hanya dibedakan oleh satu atau beberapa pita DNA. Pita DNA pembeda tersebut tidak sama untuk masing-masing klon, yang menyebabkan sangat sukar untuk menentukan perbedaan pola pita DNA genotipe normal dan tidak normal antar klon yang diuji. Hal tersebut menunjukkan bahwa adanya perbedaan fragmen DNA yang mencirikan abnormalitas pada masingmasing klon. Diduga abnormalitas disebabkan oleh adanya perubahan susunan oligonukleotida pada untai DNA yang terjadi secara acak, dan berbeda untuk masing-masing klon. Darussamin dan Nurhaimi-Haris (1997) dan Nurhaimi-Haris (1998) menemukan hal yang sama pada beberapa klon SOC, LMC dan MK $(58,60,70$ dan 87$)$.

Tabel 1. Primer yang mampu membedakan genotipe normal dan abnormal pada klon kelapa sawit yang sama.

Table 1. Primers which was able to differentiate normal and abnormal genotypes in the same clones of oil palm

\begin{tabular}{|c|c|c|c|}
\hline No. & $\begin{array}{l}\text { Primer } \\
\text { Primers }\end{array}$ & $\begin{array}{l}\text { Sekuen primer } \\
\text { Primers sequences } \\
5, \ldots \ldots \ldots \ldots . . . .3\end{array}$ & $\begin{array}{c}\text { Klon yang genotipe normal dan abnormalnya yang } \\
\text { dapat dibedakan } \\
\text { Clones with normal and abnormal genotypes can be } \\
\text { differentiate }\end{array}$ \\
\hline 1. & OPA-02 & TGC CGA GCTG & MK104, MK152. \\
\hline 2. & OPA-04 & AAT CGG GCTG & MK152, \\
\hline 3. & OPB-05 & TGC GCC CTTC & MK176, MK203, MK209, MK212. \\
\hline 4. & OPB-06 & TGC TCT GCCC & MK104, MK212. \\
\hline 5. & OPC-07 & GTC CCG ACGA & MK104, MK203, MK209, MK212. \\
\hline 6. & OPC-02 & GTG AGG CGTC & MK104, MK152, MK176, MK203, MK209, MK212. \\
\hline 7. & OPC-08 & TGG ACC GGTG & MK104, MK152, MK212. \\
\hline 8. & OPC-09 & CTC ACC GTCC & MK104, MK203, MK209, MK212. \\
\hline 9. & OPE-14 & TGC GGC TGAG & MK104, MK152, MK176, MK203, MK209, MK212. \\
\hline 10. & $\mathrm{OPH}-18$ & GAA TCG GCAA & MK104, MK152, MK209, MK212. \\
\hline 11. & OPW-19 & CAA AGC GCTC & MK176. \\
\hline 12. & OPN-16 & AAG CGA CCTG & MK104, MK152, MK176, MK203, MK209, MK212. \\
\hline 13. & OPN-18 & GGT GAG GTCA & MK152, MK176, MK209, MK212. \\
\hline 14. & SC10-19 & CGT CCG TCAG & MK152, MK209. \\
\hline 15. & SC10-20 & ACT CGT AGCC & MK104, MK152, MK176, MK203, MK209, MK212. \\
\hline
\end{tabular}


Toruan-Mathius et al.

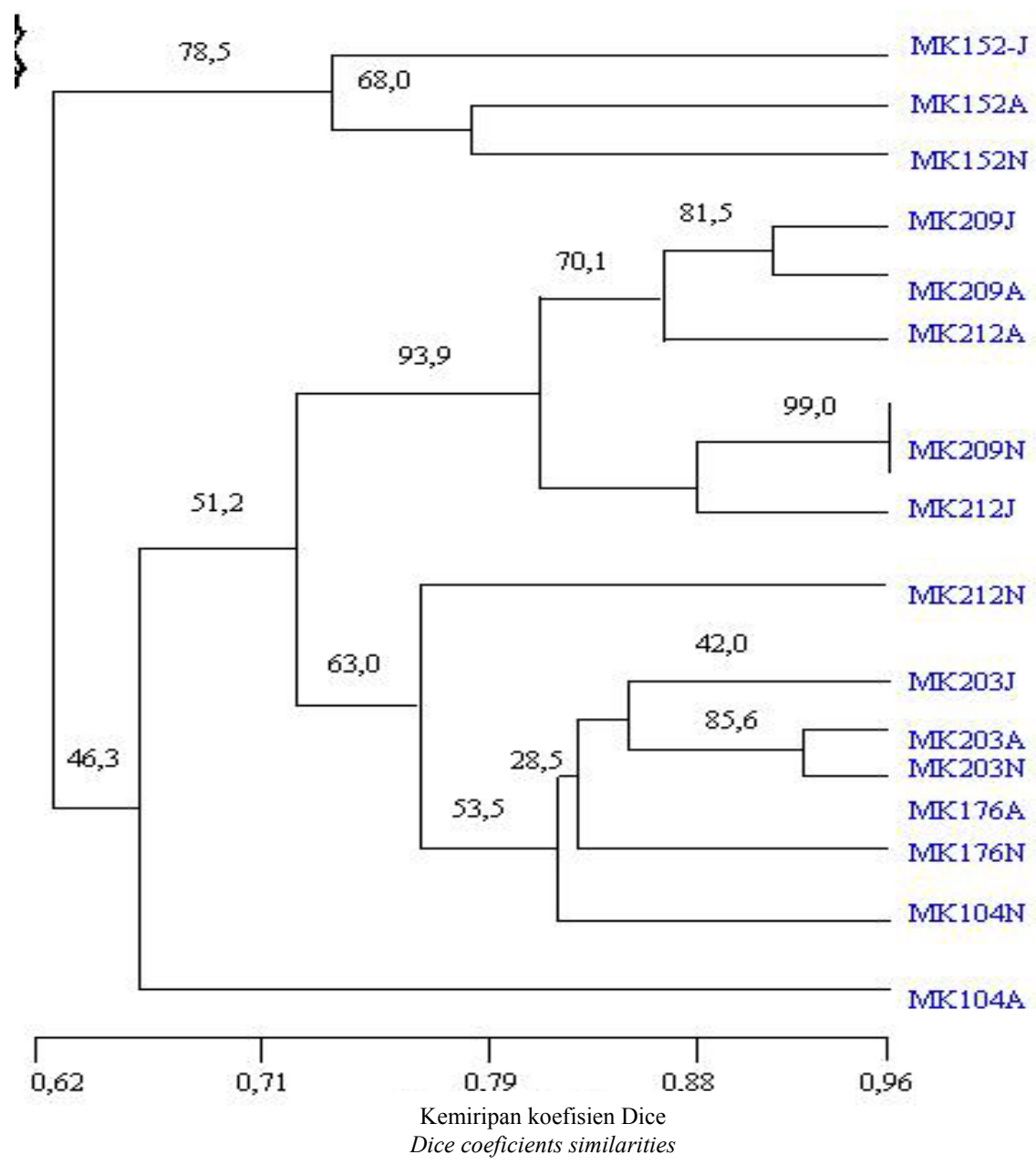

Gambar 3. Dendogram 16 genotipe klon kelapa sawit hasil analisis kluster berdasarkan pola pita DNA dengan metode UPGMA menggunakan 15 primer

Figure 3. Dendogram of 16 genotypes of oil palm clones from cluster analysis based on DNA bands patterns by UPGMA method with 15 primers. 
Analisis abnormalitas tanaman kelapa sawit......

Tabel 2. Matriks kemiripan genetik berdasarkan pola pita RAPD terhadap 16 genotipe dari 6 klon kelapa sawit

Table 2. Matrix genetic similarities based on patterns of RAPD bands on 16 genotypes of 6 oil palm clones.

$\begin{array}{llllllllllllllll}1 & 2 & 3 & 4 & 5 & 6 & 7 & 8 & 9 & 10 & 11 & 12 & 13 & 14 & 15 & 16\end{array}$

1.00

0.761 .00

$\begin{array}{lll}0.70 & 0.80 & 1.00\end{array}$

$\begin{array}{llll}0.68 & 0.68 & 0.77 & 1.00\end{array}$

$\begin{array}{lllll}0.63 & 0.65 & 0.73 & 0.91 & 1.00\end{array}$

$\begin{array}{lllllll}0.59 & 0.63 & 0.71 & 0.79 & 0.86 & 1.00\end{array}$

$\begin{array}{lllllll}0.58 & 0.64 & 0.71 & 0.78 & 0.84 & 0.96 & 1.00\end{array}$

$\begin{array}{lllllllll}0.58 & 0.65 & 0.68 & 0.85 & 0.87 & 0.83 & 0.85 & 1.00\end{array}$

$\begin{array}{lllllllll}0.56 & 0.59 & 0.69 & 0.72 & 0.80 & 0.87 & 0.89 & 0.84 & 1.00\end{array}$

$\begin{array}{llllllllll}0.47 & 0.54 & 0.66 & 0.66 & 0.68 & 0.66 & 0.66 & 0.65 & 0.75 & 1.00\end{array}$

$\begin{array}{llllllllllll}0.57 & 0.59 & 0.71 & 0.70 & 0.72 & 0.74 & 0.71 & 0.71 & 0.77 & 0.79 & 1.00\end{array}$

$\begin{array}{lllllllllllll}0.55 & 0.61 & 0.72 & 0.70 & 0.73 & 0.78 & 0.76 & 0.70 & 0.78 & 0.80 & 0.85 & 1.00\end{array}$

$\begin{array}{llllllllllllll}0.54 & 0.62 & 0.73 & 0.72 & 0.75 & 0.82 & 0.78 & 0.72 & 0.80 & 0.77 & 0.85 & 0.93 & 1.00\end{array}$

$\begin{array}{llllllllllllll}0.49 & 0.53 & 0.65 & 0.65 & 0.67 & 0.70 & 0.68 & 0.64 & 0.74 & 0.77 & 0.84 & 0.83 & 0.81 & 1.00\end{array}$

$\begin{array}{llllllllllllllll}0.54 & 0.59 & 0.58 & 0.59 & 0.59 & 0.63 & 0.62 & 0.60 & 0.64 & 0.56 & 0.73 & 0.67 & 0.69 & 0.69 & 1.00\end{array}$

$\begin{array}{llllllllllllllll}0.58 & 0.62 & 0.71 & 0.67 & 0.69 & 0.75 & 0.72 & 0.65 & 0.74 & 0.69 & 0.78 & 0.83 & 0.85 & 0.82 & 0.73 & 1.00\end{array}$

Tabel 3. Kesamaan genetik antar genotipe tanaman dari klon yang sama.

Table 3.Genetic similarities among genotypes of the same clone.

\begin{tabular}{|c|c|c|}
\hline No & $\begin{array}{l}\text { Klon dengan genotipe normal \& abnormal } \\
\text { ( } \% \text { dan berbuah mantel) } \\
\text { Clones with normal and abnormal genotypes } \\
(\% \text { and mantled fruit) }\end{array}$ & $\begin{array}{l}\text { Kesamaan genetik, \% } \\
\text { Genetic similarities, \% }\end{array}$ \\
\hline 1. & $\begin{array}{c}\text { MK152: Normal, \& berbuah mantel } \\
\text { Normal, \& mantled fruit }\end{array}$ & $0,69-0,79$ \\
\hline 2. & $\begin{array}{c}\text { MK209: Normal, \& berbuah mantel } \\
\text { Normal, \& mantled fruit }\end{array}$ & $0,78-0,96$ \\
\hline 3. & $\begin{array}{l}\text { MK212: Normal, \& berbuah mantel } \\
\text { Normal, \& mantled fruit }\end{array}$ & $0,86-0,89$ \\
\hline 4. & $\begin{array}{c}\text { MK203: Normal, \& berbuah mantel } \\
\text { Normal, \& mantled fruit }\end{array}$ & $0,75-0,85$ \\
\hline 5. & $\begin{array}{c}\text { MK176: Normal \& berbuah mantel } \\
\text { Normal \& mantled fruit }\end{array}$ & $0,81-0,82$ \\
\hline 6. & $\begin{array}{l}\text { MK104: Normal \& berbuah mantel } \\
\text { Normal \& mantled fruit }\end{array}$ & $0,68-0,73$ \\
\hline
\end{tabular}


Toruan-Mathiues et al.

Kesamaan genetik ke enam belas genotipe kelapa sawit yang diuji adalah berkisar antara 0,47 - 0,96. Kesamaan genetik 0,47 diperoleh dari MK152 berbunga jantan dengan MK203 berbunga jantan. Sedang kesamaan genetik 0,96 diperoleh dari MK212 berbunga jantan dengan MK209 berbuah normal. (Tabel 2). Sebanyak $95 \%$ dari populasi mempunyai koefisien kesamaan sekitar 0,54 - 0,89. Kesamaan genetik antar klon yang berbuah normal berkisar antara 0,71 - 0,82 yang artinya masing-masing klon memiliki kesaman genetik yang cukup tinggi. Hal ini dapat dimengerti mengingat masing-masing klon berasal dari induk dan kultur yang sama yang ditunjukkan oleh kode klon MK. Kesamaan genetik antar seluruh genotipe berbuah normal dengan genotipe abnormal (\% dan berbuah mantel) adalah berkisar antara 0,44 - 0,89. Kesamaan genetik antar genotipe abnormal antar klon berkisar antara 0,59 - 0,89. Sedang kesamaan genetik antar genotipe berbunga jantan antar klon berkisar antara 0,47-0,78.

Tampak bahwa terjadi pergeseran kesamaan genetik dari kisaran yang rendah antar klon yang normal, kearah kesamaan genetik dengan kisaran yang lebih tinggi baik antar genotipe normal dibandingkan dengan genotipe abnormal maupun antar genotipe abnormal (berbuah mantel) dan berbunga jantan. Kesamaan genetik antar genotipe dalam satu klon juga sangat beragam (Tabel 3). Tampak bahwa klon yang memiliki kisaran kesamaan genetik paling tinggi antar genotipe adalah klon MK209, sedang yang paling rendah adalah klon MK176. Hal ini menunjukkan bahwa klon MK209 mengalami perubahan genetik lebih besar dibandingkan dengan klon lainnya.

Oleh karena eksplan diberi perlakuan yang sama di dalam kultur, eksistensi keragaman genetik di dalam klon MK209 mungkin berhubungan dengan kestabilan jaringan dari klon tersebut untuk merespon perlakuan di dalam kultur. Hal sebaliknya terjadi pada klon MK176. Hasil yang diperoleh ini memperkuat dugaan bahwa abnormalitas terjadi akibat adanya perubahan dalam susunan oligonukleotida secara acak yang berbeda antar klon.

Menurut Jones et al. (1995) lamanya interval transfer, dan komposisi zat pengatur tumbuh khususnya ratio NAA/ Kinetin serta medium sangat mempengaruhi terbentuknya bunga mantel dan bunga jantan pada tanaman klon di lapang. Khususnya pada klon yang diklasifikasikan beresiko rendah dan medium dalam merespons perlakuan di dalam kultur. Perubahan di dalam memperpendek masa transfer dan menurunkan rasio konsentrasi NAA/kinetin sampai saat ini masih dalam penelitian yang intensif.

Hasil UPGMA menunjukkan bahwa 16 genotipe kelapa sawit yang diuji terbagi menjadi dua kelompok besar (klaster utama) pada tingkat kemiripan genetik sebesar 0,62. Kelompok A terdiri dari 3 genotipe klon MK152 dan kelompok B terdiri dari (B1) 12 genotipe dan (B2) MK104 abnormal. Pengelompokan MK 209 normal dengan MK212 jantan dan MK 203 normal dengan MK176 abnormal mempunyai tingkat kepercayaan yang tinggi berturut-turut $99 \%$ dan $95,6 \%$, sedang tingkat kepercayaan pengelompokan genotipe lainnya di bawah $90 \%$. Hasil yang diperoleh menunjukkan bahwa ada kecenderungan bahwa genotipe di dalam klon yang sama berada dalam kelompok yang sama (Gambar 4).

Uji lanjutan yang dilakukan terhadap 115 pita DNA yang diperoleh melalui RAPD adalah dengan melakukan analisis komponen utama. Analisis ini bertujuan mengetahui pita-pita DNA yang sangat berperan dalam pengelompokan 16 genotipe tanaman berbunga jantan, berbuah normal dan tidak normal.

Hasil analisis komponen utama yang dilakukan terhadap 115 karakter pita RAPD 
dari 15 primer pada enam klon kelapa sawit, diperoleh enam komponen utama yang mempunyai akar ciri lebih dari satu. Nilai keragaman komponen utama (KU) I yang diperoleh dapat menerangkan keragaman data asal sebesar $23 \%$, KU II mampu menjelaskan keragaman data asal juga sebesar $21 \%$, sehingga total kedua KU dapat menerangkan keragaman data asal sebesar 44\%. Angka tersebut berarti 44\% keragaman dari 115 pita RAPD yang diperoleh dengan menggunakan 15 primer pada enam individu klon kelapa sawit dapat diterangkan oleh kedua komponen utama ini (Gambar 4). Dua puluh tiga persen keragaman yang dapat diterangkan oleh KU I telah berhasil mengidentifikasi sebanyak 26 pita dari 115 pita hasil amplifikasi RAPD dengan menggunakan 15 primer acak. Untuk menentukan sebanyak 26 pita yang paling berperan dalam pengelompokkan ke enam klon kelapa sawit dipilih nilai mutlak KU yang paling besar. Begitu juga dengan KU II memiliki sebanyak $21 \%$ proporsi keragaman atau sebanyak 25 pita yang mempunyai nilai KU paling besar yang berperan dalam pengelompokan ke enam klon kelapa sawit tersebut.

Pengelompokan yang diperoleh pada diagram pencar dua dimensi hasil analisis komponen utama memperlihatkan pola sama berdasarkan dendogram (Gambar 3 \& 4 ) yang diturunkan dari matriks kemiripan genetik. Pada gambar diagram pencar dua dimensi ini terlihat MK104 berbuah tidak normal memencil.

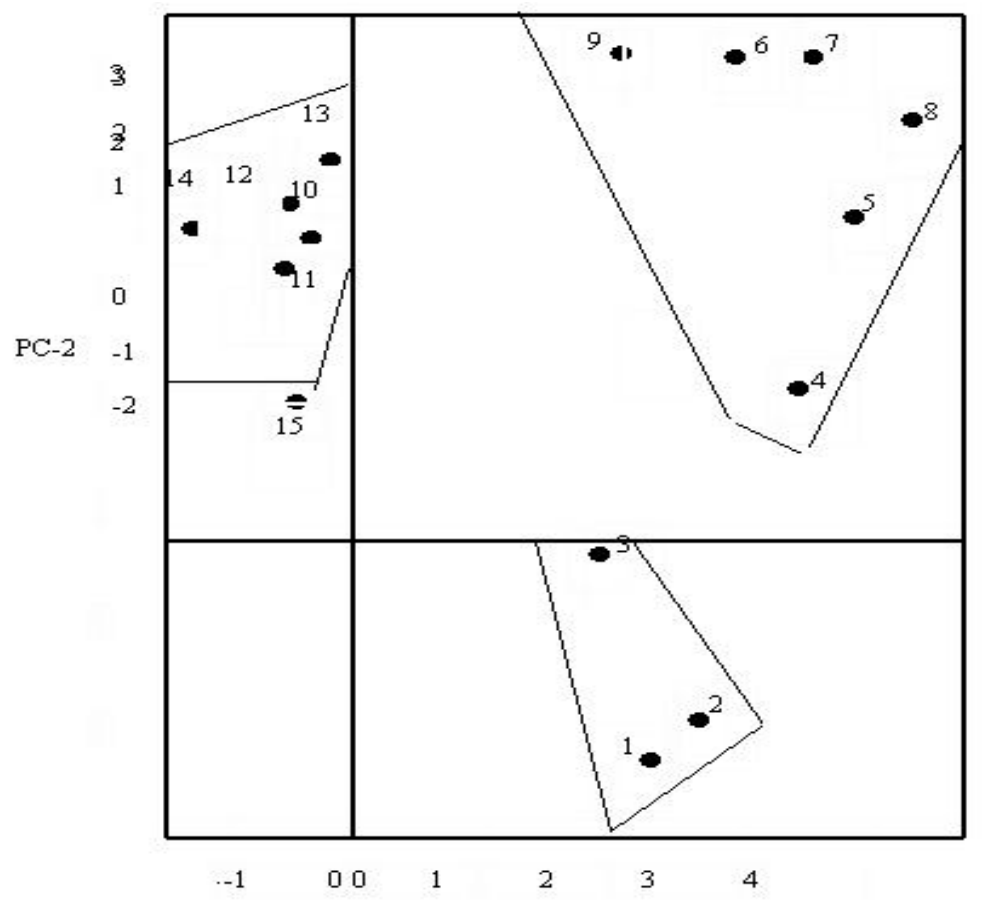

PC-1

Gambar 4. Pemetaan KU1 dan KU2 terhadap klon MK152, MK209, MK212, MK203, MK176 dan MK104.

Figure 4. KU1 and KU2 map of MK152, MK209, MK212, MK203, MK176 and MK104.

Keterangan (Explanation): MK152(1-3); MK209j, MK209a \& MK212a(4,5,8); MK209n; MK212 \& MK212n(6,7,9); MK203j \& MK203n; MK176n; MK176a (10-14); MK104n(16) and MK104a (15) 
Toruan-Matnius et al.

Berdasarkan hasil analisis komponen utama dari 15 primer yang digunakan ditemukan pita yang membedakan tanaman berbuah normal dan tidak normal pada pita ke-1, primer OPA-02 ; pita ke-3, primer OPC-02 ; pita ke-8, primer OPC-07 ; pita ke-4, primer OPH-18 ; pita ke-5 dan ke-7, primer OPW-19 dan pita ke-1, 9 dan 10, primer OPE-14.

Dari hasil yang diperoleh dapat diambil kesimpulan bahwa tidak ada satupun pita DNA dari 15 primer yang diuji dapat mencirikan abnormalitas pada semua klon yang diuji. Hal ini kemungkinan disebabkan bahwa variasi somaklonal yang terjadi pada klon-klon kelapa sawit erat hubungannya dengan perubahan dalam satu atau dua oligonukleotida pada utas DNA yang tidak dapat dideteksi dengan teknik RAPD.

Menurut Phillips et al. (1990) variasi somaklonal berhubungan erat dengan perubahan pola metilasi DNA selama dalam kultur. Gruenbaum et al. (1997) melaporkan bahwa pada tanaman tinggi metilasi DNA terjadi tersebar antar sekuens ${ }^{5 \mathrm{~m}} \mathrm{CG}$ dan ${ }^{5 \mathrm{~m}} \mathrm{CNG}$, terutama pada CTG dan CAG ( Kovarik et al., 1997), dan CCG (Jeddeloh \& Richard, 1996). Pada tanaman 5-metilsitosin dapat terjadi sebanyak 20-40\%. Metilasi pada 5CG dinukleotida dapat bersifat mutagenik dan epigenik pada berbagai aktivitas seluler (Belanger \& Hepburn, 1990). Hal ini menunjukkan bahwa untuk menganalisis abnormalitas pada tanaman kelapa sawit, salah satu kemungkinan yang dapat digunakan adalah teknik yang mampu mendeteksi perubahan dinukleotida akibat terjadinya metilasi.

\section{KESIMPULAN}

Primer RAPD yaitu OPC-08, SC10-19, OPC-07 dan OPW-19 mampu membedakan genotipe normal dan tidak normal dalam klon yang sama untuk seluruh klon yang diuji. Kesamaan genetik antar klon normal lebih tinggi dibandingkan dengan kesamaan genetik antar genotipe normal dan abnormal maupun antar genotipe abnormal. Berdasarkan kisaran kesamaan genetik antar genotipe dalam klon yang sama, klon MK176 lebih stabil di dalam kultur dibandingkan dengan klon lainnya. Berdasarkan analisis UPGMA, genotipe yang berbeda dari klon yang sama umumnya menjadi anggota dalam satu kelompok yang sama. Hasil analisis komponen utama menunjukkan bahwa dari 15 primer yang diuji belum mampu menghasilkan pita DNA penciri untuk abnormalitas.

\section{Daftar Pustaka}

Ahee, J., P. Arthuis, G. Cas, Y. Duval, G. Guenin, J.Hanower, P Hanower, D.Lievoux, C.Lioret, B.Malaurie, C.Pannetier, C.Raillot, D. Varechon \& L.Zuckermann (1981). La multiplication vegetatif in vitro du palmier a huile par embryogenese somatique. Oleagineux, 36 (3), 113118 .

Basiron, Y., Mohd. Basri Wahid \& Chan Kook Weng (2002). Advances in research and development for the oil palm industry Malaysia. In Proc. International Oil Palm Conference. Bali, 8-12 July, 2002, p.15

Belanger, F.C. \& A. Hepburn (1990). The evolution of $\mathrm{CpNpG}$ methylation in plants. J.Mol. Evol., 30, 26-35.

Bouman, H. \& G.J.De Klerk (1996). Somaclonal variation in biotechnology of ornamental plants. In R. Geneve et al (eds.) Biotechnology of ornamental plants. CAB International, 165-183.

Corley, R.H.V., C.H.Lee, I.H.Law \& C.Y.Wong (1986). Abnormal flower development in oil palm clones. The Planter, 62, 233-240. 
Analisis abnormalitas tanaman kelapa sawit.....

Duran-Gasselin, T, Y. Duval, L.Baudouin, A.B. Maheran, K.Konan \& J.M.Noire (1993). Description and degree of the mantled flowering abnormality in oil palm (Elaeis quineensis Jacq) clones produced using the Orstam-CIRAD Procedure. In Proc. of the 1993 ISOPB Int. Symp. Recent Development in Oil Palm Tissue Culture and Biotechnology. Kuala Lumpur, 14-15 September, 1993, p.48-63.

Gruenbaum, Y., T. Navey-Many, H. Cedar \& A. Razin (1981). Sequence specificity of methylation in higher plant DNA. Nature, 292, 680-682.

Jeddeloh, L.A.\& E.J. Richard (1996). (m) CCG methylation in angiosperm. Plant J., 9 (5), 579-586.

Jones, L.H. (1991). Endogenous cytokinin in oil palm (Elaeis guieneensis Jacq.) callus, embryoids and regenerant plants measured by radio immunoassay. Plant Cell Tiss. \& Org. Cult., 20, 201-209.

Jones, L.H., D.E. Hanke \& C.J. Euwens (1995). An evaluation of the role of cytokinin in the development of abnormal enflorescences in oil plam (Elaeis guineensis Jacq) regenerared from tissue culture. J. Plant Growth Regul., 14, 135-142.

Karp, A. (1995). Somaclonal variation in crop improvement. Euphytica, 185, 295-302.

Kovarik, A., R. Matyasek, A. Leitch, B. Gazdova, J. Fulnecek \& M. Bezdek (1997). Variability in CpNpG methylation in higher plant genomes. Gene, 204(12), 25-33.

Larkin, P.J. \& W.R. Scowcroft (1981). Somaclonal variation- a novel source of variability from cell cultures for plant improvement. Theor. Appl. Genet., 60, 197-214.

Meyer, P., I. Neidenhof \& M. Ten Lohuis (1994). Evidence for cytosine methylation of non-symetrical sequences in transgenic Petunia hybrids. EMBO J., 13, 2084-2088.

Mohan, J.S. \& G.J. De Klerk (1998) Somaclonal variation in breeding and propagation of ornemnetal crops. In IAPTC IX Int. Conggress on Plant Tissue and Cell Culture. Jerusalem, Israel, 14-19 June, 1998, 13pp.

Nei, M. \& W. Li (1979). Mathematical model for studying genetic variation in terms of restriction endonucleases. In Proc. Natl. Acad. Sci.USA., 767, 52695273.

Nurhaimi- Haris \& A. Darussamin (1997). RAPD analysis of oil palm clones with normal and abnormal fruits. Menara Perkebunan, 65, (2), 64-74.

Nurhaimi-Haris (1998). Analysis of fruiting abnormality among oil palm (Elaeis guineensis Jacq.) clones by RAPD technique. Menara Perkebunan, 66, (2), 55-63.

Orozco- Castillo, K.J. Chalmers, R.Waugh \& W. Powell (1994). Detection of genetic diversity and selective gene introgression in coffe using RAPD markers. Theor. Appl. Genet., 87, $934-$ 940 . 
Toruan-Mathius et al.

Pannetier, C., P.Arthuis \& D.Et Lievoux (1981). Neoformation de jeunes plantes d'Elaeis guineensis a partir de cals primaries obtenus sur fragments foliares cultive in vitro. Olegineux, 36, 119-122.

Paranjothy, K., R.Othman, C.C.Tan, G.Wang \& A.C.Soh (1993). Incidence of abnormalities in relation to in vitro protocols. In Proc. of the 1993 ISOPB Int. Symp. Recent Development in Oil Palm Tissue Culture and Biotechnology. Kuala Lumpur, 14-15 September, 1993, p.77-85.

Peshke, V.M. \& R.L. Phillips (1992). Genetic implications of somaclonal variation in plants. $A d v$. Genet., 30, 4147.

Phillips, R.L., D.J. Plunkett \& S.M. Kaeppler (1990). Do we understand somaclonal variation ?. In " Progress in Plant Cellular and Molecular Biology". In Proc. $7^{\text {th }}$ Intl. Congr. Plant Tissue Cell Cult., p.131-141.

Rao, V. \& C.R. Danaough (1990). Preliminary evidence of a genetic cause for the floral abnormalities in some oil palm ramets. Elaeis, 2(2), 199-207.

Rohlf, F.J. (1993). NTSYS - PC. Numerical Taxonomy and Multivariate Analysis System. New York, Exeter Software, p. $10-13$.
Sambrook, J., E.F.Fritsch \& T. Maniatis (1989). Moleculer cloning: A laboratory manual. New York, Cold Spring Harbour Lab. Press, p. 6.1-6.7. Skirvin, R.M., K.D. McPheeters \& M. Norton (1994). Source and frequency of somaclonal variation. Hort Sci., 29, 1232-1237.

Tingey, S.V., J.A. Rafalski \& J.G.K Williams (1992). Genetic Analysis With RAPD Markers. In Application of RAPD Technology to Plant Breeding. Joint Plant Breeding Symposia Series CSSA/ASHS/ AGA. Minneapolis, 1 September 1992, p. 3 8.

Toruan-Mathius, N. \& T. Hutabarat (1997). Analysis of genetic integrity of banana planlets from in vitro culture by Random Amplified Polymorphic DNA (RAPD). Menara Perkebunan, 65(1), 17-25.

Williams, J.G.K., A.R.Kubelik, K.J. Livak, J.A. Rafalski \& S.V.Tingey (1990). DNA Polymorphism amplified by

arbitrary primers are useful as genetic markers. Nuc. Acid Res., 18 (22), 65316535.

Yap, I.V. \& R.J. Nelson (1996). WinBoot. IRRI Manila. p. 22-25. 